\title{
A QUALITATIVE STUDY ON \\ TRANSFERRING THE EXPERIENCE OF USING TECHNOLOGY FROM FORMAL EDUCATION TO DISTANCE EDUCATION
}

\author{
Research Assistant Merve YILDIZ \\ Department of Computer and Instructional Technology Education \\ Faculty of Education, Erzincan University, TURKEY \\ Assist. Prof. Dr. Yavuz SELIM \\ Department of Computer Education and Instructional Technology \\ Faculty of Education, Erzincan University, TURKEY
}

\section{ABSTRACT}

With improvements in information technologies, distance education programs have become widespread. Institutions that offer distance education programs are increasing in number. Scholars who were used to face-to-face teaching began to give courses in distance education programs which entail technological teaching methods, a new teaching experience for the teachers.

Formal education or face-to-face education and distance education have different dynamics. The transition to distance teaching from the first to the later involves the transmission of experiences of teaching with technology. For effective distance education, it is important to analyze the transmission of these teaching experiences. This study evaluates how faculty members' experiences with technologies in formal education are transmitted to distance education. Interviews were held with twelve scholars who have taught both formal and distance learning courses. The interviews were recorded. Content analysis method was used to obtain a deeper understanding of the data collected.

It was found that the teaching materials used in the formal and distance educations were exactly the same. Some faculty members claimed that infrastructure and technical possibilities of the current system were not sufficient for the use of different teaching materials. However, this study suggests that teachers' beliefs about educational methods are the main reason that prevented the use of different teaching materials in distance education.

Keywords: Distance education, formal education, use of technology, experience, transmission, belief.

\section{INTRODUCTION}

Improvements in information and communication technologies enhance teaching and learning environments. In particular, internet technology helps improve education. The use of internet technology has made possible an educational system free of space and time constraints, namely, distance education. This refers to "an interactive and systematic educational process involving the use of technology and media, without space and time constraints." (Gulbahar, 2009; Kaya, 2002; Simonson, 2001; Keegan, 1986). Given that distance education eliminates space and time constraints, the increasing demand for lifelong learning and distance education programs is obvious. In this regard, universities 
try to achieve an effective integration of information and communication technologies in their educational programs and to meet this increasing demand.

Good planning, design, management and evaluation are required for distance learning courses to be effective. Yet this does not mean that a good structured distance learning program will always be successful. Beliefs about education have a decisive role in achieving educational goals. Beliefs about education affect pedagogic beliefs, and pedagogic beliefs affect in turn beliefs in technology and its usage (Pajares, 1992). In other words, there is a linear relationship between belief and practice. Many teachers use technology without changing their pedagogic perspective on education (Zhao ve Cziko, 2001).

The teacher-centered approach to teaching does not support the use of technology in classroom, or favors its use to the extent that it helps the traditional teaching methods to persist. Teachers who accept teacher-centered approach do not consider technology as an innovation. When they encounter a different educational system as distance education, they are unable to use it effectively. However, student-centered approach to teaching does not consider technology merely as a means, but an innovation to enhance the effectiveness of teaching. Teachers who favor a student-centered approach use the technologies available in the system in the most effective way (Niederhauser \& Stoddart, 2001).

Contrary to their experiences and observations, teachers have a prejudice against the use of technology in education. Teachers' personal lives, perceptions, experiences and beliefs all affect their attitude towards a new situation. When they encounter a new technology, they tend to use it as suits their past experiences and beliefs (Kagan, 1992).

This study evaluates how faculty members' experiences with technologies in formal education are transmitted to distance education. It thus reveals the relation between teachers' beliefs about the use of technology and their practices with technologies. The aim of this study was to contribute to the enhancement of the effectiveness of distance education.

\section{METHOD}

Qualitative research methods were used since this study evaluates how the faculty members' experiences with technologies in the formal education are transmitted to the distance education.

\section{Research Sample}

This research was done with twelve scholars who have taught both formal and distance education at Erzincan University. Table-1 presents participants' demographic data. 
Table: 1

Participants' demographic data

\begin{tabular}{|c|c|c|c|}
\hline & & f & $\%$ \\
\hline \multirow{2}{*}{ Gender } & Male & 10 & 83.33 \\
\hline & Female & 2 & 16.67 \\
\hline \multirow{4}{*}{ Age } & $26-30$ & 7 & 58.33 \\
\hline & 31-35 & 2 & 16.67 \\
\hline & $36-40$ & 1 & 8.33 \\
\hline & 50 and above & 2 & 16.67 \\
\hline \multirow{3}{*}{ Educational Level } & Undergraduate & 2 & 16.67 \\
\hline & Master's & 6 & 50.00 \\
\hline & PHD & 4 & 33.33 \\
\hline \multirow[b]{2}{*}{ Fields of Specialization } & Qualitative & 8 & 66.67 \\
\hline & Quantitative & 4 & 33.33 \\
\hline \multirow{4}{*}{ Academic Experience } & 1-5 years & 9 & 75.00 \\
\hline & $6-10$ years & 1 & 8.33 \\
\hline & $10-15$ years & 1 & 8.33 \\
\hline & $25-30$ & 1 & 8.33 \\
\hline \multirow{3}{*}{$\begin{array}{l}\text { Distance Education } \\
\text { Experience }\end{array}$} & 4 semesters & 6 & 50.00 \\
\hline & 2 semesters & 3 & 25.00 \\
\hline & 1 semester & 3 & 25.00 \\
\hline
\end{tabular}

\section{Data Collection Tools}

Researchers classified data collection tools in two categories. The first category included questions about demographic data, and the second category included interview questions.

\section{Interview Questions:}

$>$ Which technologies do you use in formal education?

$>$ How do you transmit your experiences with technology to distance education?

$>$ Did you participate in a training, seminar or any other activity before you began to teach distance education courses?

$>$ If you were unfamiliar with using technology in your formal education courses, would you have difficulty teaching distance education?

$>$ What are the problems you had using technology in formal or distance education?

$>$ What are your suggestions to solve the problems you faced?

\section{Data Analysis}

Interviews were held with twelve scholars who participated in the research in accordance with the principle of voluntariness. The interviews were recorded.

The content analysis method was used to ensure a deep understanding of the data collected and to determine themes and dimensions not previously identified. Data analysis includes four stages: data coding, identifying the themes, arrangement of the 
codes and themes, and defining the findings and interpretation (Yildirim and Simsek, 2008).

The researchers categorized the data in different codes, and by comparing the themes and codes they ensured consistency.

\section{FINDINGS}

The research findings and the themes that emerged were indicated in terms of frequency and percentage. The quantitative data for each question was matched with statements from the interviews in order to support the quantitative findings.

Technologies Used in Formal Education

Almost all the participants $(91.67 \%)$ said that slide projectors were the most commonly used technology in formal education.

PowerPoint was the most commonly used teaching technology $(58.33 \%)$.

Table: 2

Technologies Used in Formal Education

\begin{tabular}{lcc}
\hline & f & $\%$ \\
\hline Slide Projector & 11 & 91.67 \\
PowerPoint & 7 & 58.33 \\
Blackboard & 7 & 58.33 \\
Computer & 5 & 41.67 \\
Internet & 2 & 16.67 \\
Courses & 2 & 16.67 \\
Smart board & 1 & 8.33 \\
Visual resources (pictures, cartoons, etc.) & 1 & 8.33 \\
Occupational tools/techniques & 1 & 8.33 \\
\hline
\end{tabular}

"I'm an instructor in the department of Turkish Language and Literature. Sometimes students are annoyed with the linguistic topics. To grab students' attention, I need to use visual resources such as slides or cards. Unfortunately, cards have a pejorative meaning for the university students. They say cards are used in high school teaching, and not in university courses. So I mostly use a projector to show slides. " [Participant-2]

"We use generally white boards for formal education courses. We also have slide projectors and personal computers." [Participant-4]

\section{The Transmission of Experiences with Technology}

in Formal Education to Distance Education

In response to the question, "How do you transmit your experiences with technology in formal education to distance education?" most of the participants $(83.33 \%)$ said, "We download presentation files to the system and use them for distance education courses." 
Table: 3

The Transmission of Experiences with Technology

in Formal Education to Distance Education

\begin{tabular}{lcc}
\hline & $f$ & $\%$ \\
\hline $\begin{array}{l}\text { We download presentation files to the system and use them for } \\
\text { distance education courses. }\end{array}$ & 10 & 83.33 \\
\hline
\end{tabular}

"Since distance education involves mostly slide shows, we transfer to the distance education system the presentation files that we had already prepared for formal education courses. Apart from that, my courses in general..., that means, I did not use them frequently. We only showed slides." [Participant-10]

"We did not have difficulty transferring the files. Since we often used slide shows for our formal education courses, we easily transferred them to distance education courses." [Participant-4]

"I need to say that we only transfer presentations. We don't use advanced technology in distance education. There are limited possibilities offered to us, and we don't even use them in an effective way.

Actually, there are technical problems that prevent an effective usage. For instance, in a case that our presentations remain insufficient, we need to give examples to make the topic understandable.

But, we do not have an opportunity to use actively different teaching materials. White boarding can be used, but this is a time limited practice." [Participant-5]

Participation in a Training, Seminar or

any other Activity before Teaching Distance Education Courses

In the interviews ten participants said they participated in an introductory meeting arranged by the educational center.

However, two participants said they did not participate in any activity before they began to teach distance education courses.

Table: 4

Participation in Distance Education Activity

\begin{tabular}{lcc}
\hline & f & $\%$ \\
\hline Yes, I joined & 10 & 83.33 \\
No, I didn't joined & 2 & 16.67
\end{tabular}

"Naturally, we had in-service training at the university distance education center. In this training we were briefly informed about the planning of the course schedule and that was sufficient." [Participant-9]

Having No Experience with Technology in Formal Education and Having Difficulty Teaching for Distance Education Courses

Of nine research participants, 3 said they were not competent in the use of technology and have difficulty using it, and 6 said it was easy to use technology although they had no experience since they were able to learn to use it quickly. 
Table: 5

The Effects of Using Technology in Teaching for Distance Education Courses

\begin{tabular}{lcc}
\hline & f & $\%$ \\
\hline No, I would not have difficulty & $\mathbf{6}$ & $\mathbf{5 0 . 0 0}$ \\
Yes, I would have difficulty & 3 & 25.00 \\
No response & 3 & 25.00
\end{tabular}

"If a scholar is competent in teaching, technology does not cause problems. Since technology is sufficiently advanced, no problems emerge. Even if I were unfamiliar with a technology, I would not have a problem using it." [Participant-8]

"We would certainly have difficulty. Boards give us a large space to use. They are more comfortable. You can write on the boards." [Participant-3]

\section{Problems with the Use of Technology in Formal and Distance Education}

Table 6 presents faculty members participated in the study, problems encountered in the use of technology face to face training and distance education.

Table: 6

Problems with the Use of Technology in Formal and Distance Education

\begin{tabular}{|c|c|c|}
\hline & & $\mathbf{f}$ \\
\hline \multirow[t]{2}{*}{$\begin{array}{l}\text { Technical } \\
\text { Infrastructure and } \\
\text { Equipment }\end{array}$} & $\begin{array}{l}\text { Problems which emerge in formal education } \\
\text { can be solved immediately, but that is } \\
\text { not the case for distance education in which } \\
\text { technical infrastructure is connected to an integrated system. }\end{array}$ & 5 \\
\hline & $\begin{array}{l}\text { Since the technologies used in formal and distance } \\
\text { education are very limited, they do not cause any problems. }\end{array}$ & 4 \\
\hline \multirow[t]{2}{*}{ Course Preparation } & $\begin{array}{l}\text { Course preparation in distance education } \\
\text { requires careful preparation and time. }\end{array}$ & 5 \\
\hline & $\begin{array}{l}\text { Since students do not have preliminary } \\
\text { knowledge, it is hard to organize a course. }\end{array}$ & 2 \\
\hline \multirow{3}{*}{ Interaction } & $\begin{array}{l}\text { Contrary to formal education, distance education } \\
\text { has very limited possibilities for interaction. }\end{array}$ & 5 \\
\hline & Student participation is very low in distance education. & 5 \\
\hline & $\begin{array}{l}\text { Since distance education requires a constant control } \\
\text { of multiple technologies, an interactive classroom } \\
\text { atmosphere does not exist. }\end{array}$ & 2 \\
\hline \multirow{4}{*}{ Methods } & $\begin{array}{l}\text { We download presentation files to the system and } \\
\text { use them in distance education courses. }\end{array}$ & 10 \\
\hline & An applied course is very hard to organize in distance education. & 3 \\
\hline & $\begin{array}{l}\text { Since we teach low-achieving students, it is not } \\
\text { possible to use different teaching models. }\end{array}$ & 2 \\
\hline & $\begin{array}{l}\text { Since scholars have heavy teaching loads, } \\
\text { they cannot do many different things with technologies. }\end{array}$ & 1 \\
\hline \multirow{3}{*}{$\begin{array}{l}\text { Classroom } \\
\text { Management }\end{array}$} & $\begin{array}{l}\text { Students can give instant feedback in formal } \\
\text { education, while feedback requires time in distance education. }\end{array}$ & 6 \\
\hline & $\begin{array}{l}\text { Students can use the messaging system inappropriately, } \\
\text { and this negatively affects the course and motivation levels. }\end{array}$ & 5 \\
\hline & $\begin{array}{l}\text { A course which takes two or three weeks to complete, } \\
\text { takes two hours in distance education. }\end{array}$ & 2 \\
\hline
\end{tabular}


"I have problems with technologies I use at work. Since distance education involves an integrated structure, problems are caused by the system. It takes time to solve a problem." [Participant-1]

"You do not have a face-to-face contact, and you cannot get feedback. You don't know whether students understand your explanations. You don't know students' knowledge levels, so you assume an intermediate level and teach accordingly." [Participant-2]

"I think distance education is a very abstract teaching model in which there is no face-toface contact. I consider face-to face contact to have an important role in creating an interactive classroom atmosphere." [Participant-11]

"I began to work at the university in 1979. And I am highly experienced. Most scholars prefer teaching formal education courses because course preparation in distance education requires time. I've been preparing a distance education course for six months, and I have never prepared a course so carefully before." [Participant-7]

"Distance education needs to be taken seriously because it requires careful course preparation. In formal education a great part of class time is devoted to classroom interaction, but we don' have this opportunity in distance education. A topic that is covered in an hour in a formal education course, is covered in ten or fifteen minutes in a distance education course. You keep on teaching since you don't get any feedback." [Participant-10]

"A topic that is covered in three hours or six hours over two weeks in a formal education course can be covered in an hour in a distance education course. Classroom interaction doesn't exist in distance education, so scholars need to prepare courses carefully. This puts great pressure on scholars." [Participant-5]

"If we don't find a way to achieve student participation, distance education will not work effectively. I am worried about that. When students are not physically present in the class, we do not know whether they understand our explanations." [Participant-10]

"There are students who constantly ask whether we can see or hear them. They try to spend class time in this way.

They wish to disrupt the class. I think this is a great disadvantage, and you have no chance to test whether they are telling the truth. So you are obliged to deal with technical issues during class time." [Participant-2]

Suggestions to Solve the Problems

with the Use of Technology in Formal and Distance Education

Table 7 presents faculty members participated in the study, solutions to problems encountered in the use of technology proposals face to face training and distance education. 
Table: 7

Suggestions to Solve the Problems with the Use of Technology in Formal and Distance Education

\begin{tabular}{lll}
\hline & $\begin{array}{l}\text { Courses need to be prepared in a studio. Class time } \\
\text { needs to be arranged in a question and answer } \\
\text { format. }\end{array}$ & $\mathbf{4}$ \\
\hline $\begin{array}{l}\text { Technical Infrastructure } \\
\text { and Equipment }\end{array}$ & $\begin{array}{l}\text { Infrastructure needs to be improved, and } \\
\text { technologies need to be updated. }\end{array}$ & $\mathbf{3}$ \\
\cline { 2 - 3 } & $\begin{array}{l}\text { Technical service is needed to reduce the problems } \\
\text { facing teachers and students in distance education. }\end{array}$ & $\mathbf{1}$ \\
\hline Course Preparation & Scholars' teaching loads need to be reduced. & 2 \\
\hline Classroom Interaction & Students' active participation needs to be ensured. & 2 \\
\hline Methods & $\begin{array}{l}\text { A system like smart board can allow for fluent } \\
\text { teaching. }\end{array}$ & 2 \\
\hline Classroom Management & In-service training for scholars needs be organized. & 2 \\
\hline
\end{tabular}

"There can also be connection problems. My suggestion is to record the courses in a studio. It will create an active atmosphere. $I$ think it is necessary to devote class time to question and answer dialogues, which creates an interactive examination of the course topic." [Participant-5]

"Institutions that offer distance education programs need to have low teaching loads. We have a load of more than $\mathbf{3 0}$ hours per week at this university. Distance education is a teaching system that requires time." [Participant-10]

"I have doubts about our possibilities to use technologies in the course. We are not competent in using technology. As you know, technological improvements bring about radical changes in our life. I think sharing information about technological developments will be useful." [Participant-7]

\section{CONCLUSION AND DISCUSSION}

It was found that slide projectors were the most commonly used technology in formal education. Other commonly used technologies are PowerPoint and blackboards.

Almost all of the scholars said they used exactly the same teaching materials in formal and distance education. In formal education, slide projectors were the most commonly used technology, while in distance education cameras and microphones were used most. Some scholars claimed that the system's inadequate technical possibilities prevented the use of different teaching materials.

However, this study suggests those teachers' beliefs about educational methods to be the main reason that prevents the use of different teaching materials in distance education. Scholars said they used exactly the same teaching materials in formal and distance education. This finding supports Zhao and Cziko's (2010) argument that scholars use technology without changing their pedagogic perspectives. Scholars said the use of technology was very limited, particularly, in technical and applied courses, and that these technologies could not rival classroom interaction.

Some participants said the course preparation required more time in distance education. They emphasized the difficulty of teaching over the internet and of interacting with students. They also indicated the difficulty of using at the same time teaching materials and technologies such as computer, camera, microphone, and that the classroom atmosphere of formal education did not exist in distance education. 
Moreover, technical problems and insufficient equipment were considered the main reason for the problems they have with using the technologies. Scholars said that in formal education they could instantly handle problems that arise, but such rapid interventions were not possible in distance education.

\section{SUGGESTIONS}

The most remarkable finding of this study was that scholars used exactly the same teaching materials in both formal and distance education, with no concern for the different dynamics of the two teaching systems.

A good structured system has an important role in the success of a teaching model. Yet a good structured system is not sufficient by itself to ensure effective education. System users also affect the efficiency of a system. Thus scholars' beliefs about education need to be analyzed before making structural changes in education. Such an analysis is necessary for a teaching model to achieve its aims.

Authors' Note: This research is the extended version of the papers presented at the 8th International Computer \& Instructional Technologies Symposium on 1820 September 2014, at Trakya University in Edirne, Turkey.

\section{BIODATA and CONTACT ADDRESSES of the AUTHORS}

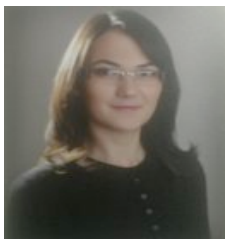

Merve YILDIZ is a research assistant of Computer and Instructional Technology Education at Erzincan University in Erzincan, Turkey. She graduated from Anadolu University in 2011 and continues to her master education at Hacettepe University. Her research interests include the distance education, e-learning, technology integration, teacher's belief.

Research Assistant Merve YILDIZ

Department of Computer and Instructional Technology Education

Faculty of Education, Erzincan University, TURKEY

Phone: 04462240089 - 42109

Mobile: 05354161257

Email: merveyildiz@erzincan.edu.tr

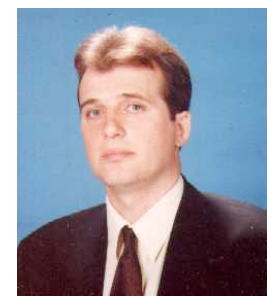

Dr. Yavuz SELIM is an assistant professor of Computer and Instructional Technology Education at Erzincan University in Erzincan, Turkey. At the same time he is a director of Distance Education Practice and Research Center at Erzincan University since 2011. In 2009 he received the PhD. grade in Secondary Mathematics Education at Atatürk University. His research areas are; distance education, technology education, computer aided education, mathematics education.

Assist. Prof. Dr. Yavuz SELIM

Department of Computer Education and Instructional Technology

Faculty of Education Erzincan University, TURKEY

Phone: 04462240089 - 42157

Mobile: 05064660876

Email: yselim@erzincan.edu.tr 


\section{REFERENCES}

Gulbahar, Y. (2009). E-learning. Ankara: Pegem Academy.

Kagan, D. M. (1992). Implications of research on teacher belief. Educational Psychologist, $27(1), 65-90$.

Kaya, Z. (2002). Distance Education. Ankara: Pegem Academy.

Keegan, D. (1986). The foundations of distance education. London: Croom Helm.

Niederhauser, D. S., \& Stoddart, T. (2001). Teachers' instructional perspectives and use of educational software. Teaching and Teacher Education, 17, 15-31.

Pajares, M. F. (1992). Teachers' beliefs and educational research: Cleaning up a messy construct. Review of Educational Research, 62 (3), 307-332.

Simonson, M. (2001). Distance education and online instruction: Profession or Field?. The Quarterly Review of Distance Education, 2 (4), 301-302.

Yildirim, A. \& Simsek, H. (2008). Qualitative Research Methods in Social Sciences (7th edition). Ankara: Seçkin Publishing.

Zhao, Y., \& Cziko, G. A. (2001). Teacher adoption of technology: A perceptual control theory perspec- tive. Journal of Technology and Teacher Education, 9 (1), 5-30. 